\title{
From Boom to Bust: The Economic Crisis in Spain 2008-2013
}

\section{INTRODUCTION}

The economic crisis that hit the country in 2008 cannot be separated from the subsequent financial crisis. In order to contextualize the banking games that inform the next chapters and to understand the overall consequences that the economic crisis had on Spanish banks and cajas, this chapter examines the economic crisis and analyzes its causes and consequences. Yet again, the performance of the Spanish banking system was deeply connected to the performance of the Spanish economy, and progress in the banking sector was marred by the performance of the Spanish economy at large. The economic crisis that started in 2008, part of the great recession that engulfed most countries, had profound consequences for the Spanish banking system. This book will show that the financial crises were the result of a political bargain in which incentives and a lax regulatory framework favored developers, property owners, and bankers, thus confirming a central tenant: the crucial importance of domestic political institutions, the rules of the game, and the role of domestic players operating within those institutions.

From: Sebastián Royo, "After Austerity: Lessons from the Spanish Experience," in Towards a Resilient Eurozone: Economic, Monetary and Fiscal Policies, ed. John Ryan (New York: Peter Lang, 2015).

(C) The Author(s) 2020

S. Royo, Why Banks Fail, https://doi.org/10.1057/978-1-137-53228-2_4 
The 2008 economic crisis, while not fully unexpected, came as a relative surprise given the strong performance of the Spanish economy during the first years of the twentieth century. The overall pattern of Spanish economic history has been described, crudely, as a graph shaped like an upside-down version of the letter ' $\mathrm{V}$ '. That is, the graph rises-bumpily at times, through 600 years under the Romans, 700 years under or partly under the Moors, and a century of empire-building-to the peak of Spanish power in the sixteenth century. After that, the history of the nation goes downhill until the 1970s. A vast empire was gradually lost, leaving Spain poor and powerless. And there was much political instability: Spain suffered forty-three coup d'états between 1814 and 1923, a horrendous civil war between 1936 and 1939, followed by thirty-six years of dictatorship under Generalísimo Franco. ${ }^{1}$

After Franco's death in 1975, the graph turned upward again. King Juan Carlos, Franco's heir, oversaw the return of democracy to the country. A negotiated transition period, which has been labeled as a model for other countries, paved the way for the elaboration of a new Constitution, followed by the first free elections in almost forty years. These developments were followed by the progressive return of Spain to the international arena-where they have been relatively isolated during the dictatorship. The following decade also witnessed the Socialist Party being elected to actual power in 1982, bringing a new aura of modernity to the country. The 1980s also witnessed Spain's integration into NATO (1982) and the European Community (1986). The following two and a half decades were a period of phenomenal growth and modernization.

Indeed, before the global crisis that hit Spain in the spring of 2008 the country had become one of Europe's most successful economies. ${ }^{2}$ While other European countries had been stuck in the mud, Spain performed much better at reforming its welfare systems and labor markets, as well as improving flexibility and lowering unemployment. Over the decade and a half that preceded the 2008 global financial crisis, the Spanish economy seemed to had been able to break with the historical pattern of boom and bust, and the country's economic performance was nothing short of

\footnotetext{
'See "After the Fiesta," The Economist, 25 April-1 May 1992, p. 60.
}

${ }^{2}$ This chapter draws upon S. Royo, From Social Democracy to Neoliberalism (New York: St. Martin's Press, 2000); S. Royo, Varieties of Capitalism in Spain (New York: Palgrave, 2008); and S. Royo, Lessons from the Economic Crises in Spain (New York: Palgrave, 2013). 
remarkable. Yet all this came to a halt when the global financial crisis hit Spain in 2008. As a result, Spain is suffering one of the worst crises since the 1940s (Royo 2013).

Following the transition to democracy and the country's European integration, Spain was, prior to the 2008 crisis, a model country. But then the (debt fueled) dream was shattered and the country's economy imploded after 2008. How did this happen? Policy choices and the structure of decision making; the role of organized interest; the structure of the state; and institutional degeneration all played an important role in explaining the severity of the economic crisis in Spain; as did the country's membership under an incomplete monetary union. The country had to face a triple crisis: financial, fiscal, and competitiveness. This chapter seeks to provide an overview of the country's evolution since the transition to democracy, and to explain its economic collapse after 2008 (see Royo 2000, 2008, 2013).

The first section of the chapter outlines the main features of the Spanish growth model, and the challenges that it faced. Section two describes the scale of the shock it underwent from 2008 onward and analyzes the triple crisis in financial, fiscal, and competitiveness performance. The chapter concludes with brief lessons from the Spanish experience.

\section{The Miraculous Decade ${ }^{3}$}

European integration was instrumental in the modernization of the country. Indeed, before the global crisis that hit Spain in the spring of 2008 the country had become one of Europe's most successful economies (see Table 4.1). Propped up by low interest rates and immigration, Spain was (in 2008) in its fourteenth year of uninterrupted growth and it was benefiting from the longest cycle of continuing expansion of the Spanish economy in modern history (only Ireland in the Euro zone has a better record), which contributed to the narrowing of per capita GDP with the EU. Indeed, in 20 years per capita income grew 20 points, one point per year, to reach close to $90 \%$ of the EU15 average. With the EU25, Spain already reached the average in 2008 . The country grew on average 1.4 percentage points more than the EU since 1996.

\footnotetext{
${ }^{3}$ This section Borrows from S. Royo, Varieties of Capitalism in Spain (New York: Palgrave, 2008).
} 


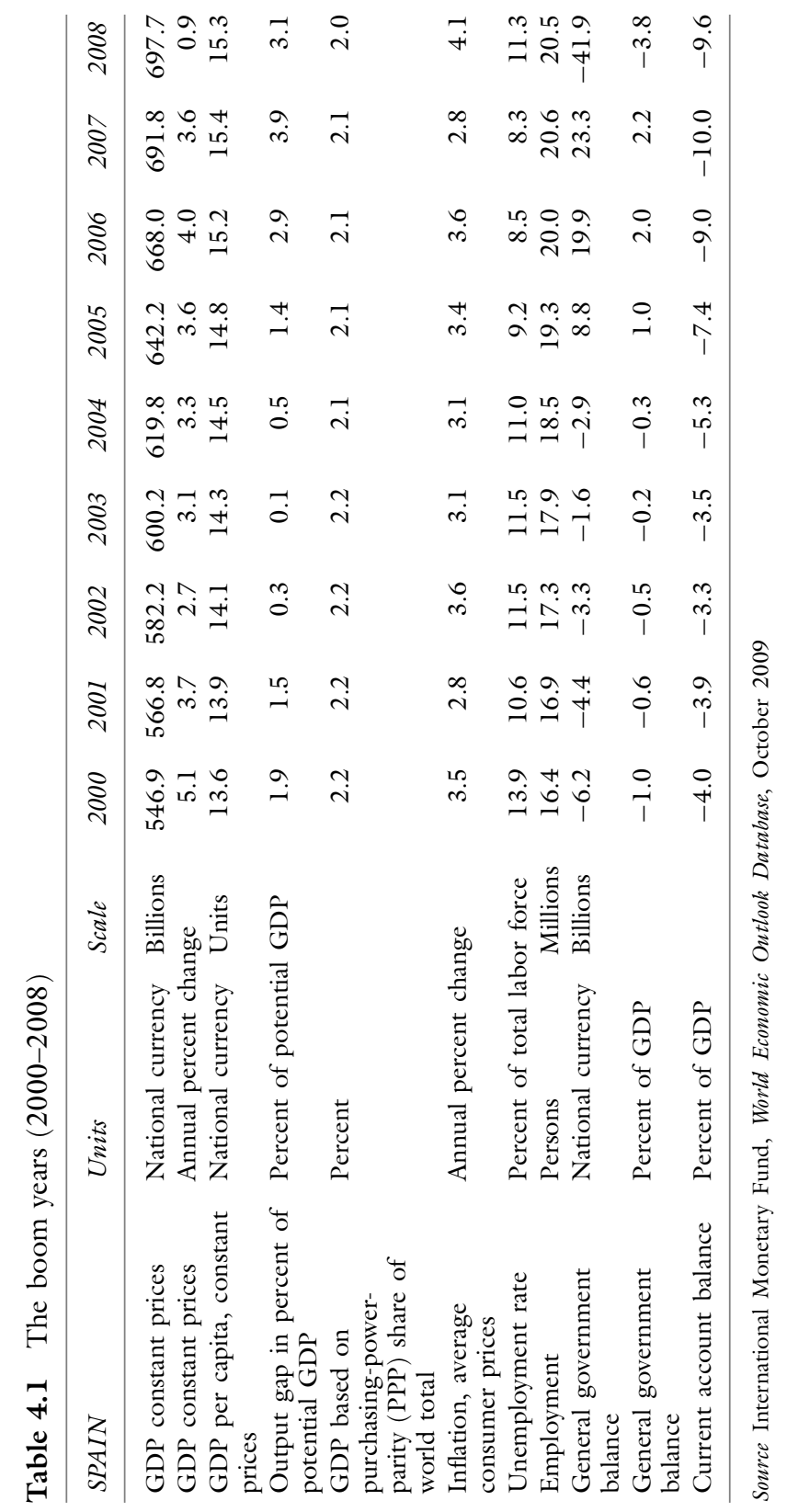


Unemployment fell from $20 \%$ in the mid-1990s to $7.95 \%$ in the first half of 2007 (the lowest level since 1978), as Spain became the second country in the EU (after Germany with a much larger economy) creating the most jobs (an average of 600,000 per year over that decade). In 2006, the Spanish economy grew a spectacular 3.9\%, and 3.8\% in 2007. As we have seen, economic growth contributed to per capita income growth and employment. Indeed, the performance of the labor market was spectacular: Between 1997 and 2007, 33\% of all the total employment created in the EU-15 was created in Spain. In 2006, the active population increased by $3.5 \%$, the highest in the EU (led by new immigrants and the incorporation of women in the labor market, which increased from $59 \%$ in 1995 to $72 \%$ in 2006 ); and 772,000 new jobs were created.

The economic success extended to Spanish companies, which expanded beyond their traditional frontiers (Guillén 2005). In 2006, they spent a total of $€ 140$ billion on domestic and overseas acquisitions, putting the country third behind the UK and France in the EU. Of this, $€ 80$ billion were to buy companies abroad (compared with the $€ 65$ billion spent by German companies). In 2006, Spanish Foreign Direct Investment (FDI) abroad increased $113 \%$, reaching $€ 71.5$ billion (or the equivalent of $7.3 \%$ of GDP, compared with $3.7 \%$ in 2005). ${ }^{4}$ In 2006 Iberdrola, an electricity supplier purchased Scottish Power for $\$ 22.5$ billion to create Europe's third largest utility; Banco Santander, Spain's largest bank, purchased Britain's Abbey National Bank for \$24 billion, Ferrovial, a family construction group, concluded a takeover of the British BAA (which operates the three main airports of the UK) for $£ 10$ billion; and Telefonica bought O2, the UK mobile phone company. Indeed, 2006 was a banner year for Spanish firms: $72 \%$ of them increased their production and $75.1 \%$ their profits, $55.4 \%$ hired new employees, and $77.6 \%$ increased their investments. ${ }^{5}$

The country's transformation was not only economic but also social. The Spanish became more optimistic and self-confident (i.e., a Harris poll showed that Spaniards were more confident of their economic future than their European and American counterparts, and a poll by the Center for Sociological Analysis showed that $80 \%$ were satisfied or very satisfied with

\footnotetext{
${ }^{4}$ Emilio Ontiveros, "Redimensionamiento Transfronterizo," El Pais, July 15, 2007.

5 Deloitte's "Barometro de Empresas," from "Un año de grandes resultados," El País, Sunday, January 14, 2006.
} 
their economic situation). Spain became 'different' again and according to public opinion polls it had become the most popular country to work for Europeans. ${ }^{6}$ Between 2000 and 2007, some 5 million immigrants $(645,000$ in 2004 and 500,000 in 2006$)$ settled in Spain $(8.7 \%$ of the population compared with $3.7 \%$ in the EU15), making the country the biggest recipient of immigrants in the EU (they represented $10 \%$ of the contributors to the Social Security system). This was a radical departure for a country that used to be a net exporter of people, and more so because it was able to absorb these immigrants without falling prey (at least so far) to the social tensions that have plagued other European countries (although there have been isolated incidents of racial violence) (see Calavita 2005). ${ }^{7}$ These immigrants contributed significantly to the economic success of the country in that decade because they boosted the aggregate performance of the economy: They raised the supply of labor, increased demand as they spent money, moderated wages, and put downward pressure on inflation, boosted output, allowed the labor market to avoid labor shortages, contributed to consumption, and increased more flexibility in the economy with their mobility and willingness to take on low-paid jobs in sectors such as construction and agriculture, in which the Spanish were no longer interested. ${ }^{8}$

Indeed, an important factor in the per capita convergence surge with the EU after 2000 was the substantive revision of the Spanish GDP data as a result of changes in the National Accounts from 1995 to 2000. These changes represented an increase in GPD per capita of $4 \%$ in real terms (the equivalent of Slovakia's GDP). This dramatic change was the result of the significant growth of the Spanish population since 1998 as a result of the surge in immigration (for instance in 2003 population grew $2.1 \%$ ). The key factor in this acceleration of convergence, given the negative behavior of productivity (if productivity had grown at the EU

\footnotetext{
${ }^{6}$ According to the Financial Times, $17 \%$ of those polled selected Spain as the country where they would prefer to work ahead of the UK (15\%) and France (11\%). See "España vuelve a ser diferente," El Pais, February 19, 2007, and Financial Times, February 19, 2007.

${ }^{7}$ Calativa provides a detailed analysis of the immigration experience in Spain and exposes the tensions associated with this development. She also highlights the shortcomings of governments' actions in regard to integration, and the impact of lack of integration on exclusion, criminalization, and radicalization. See 2005 .

8 "Immigrants Boost British and Spanish Economies," Financial Times, Tuesday, February 20, 2007, p. 3.
} 
average Spain would have surpassed in 2007 the EU per capita average by 3 points), was the important increase in the participation rate, which was the result of the reduction in unemployment, and the increase in the activity rate (the proportion of people of working age who have a job or are actively seeking one) that followed the incorporation of female workers into the labor market and immigration growth. Indeed between 2000 and 2004, the immigrant population has multiplied by threefold.

As a matter of fact, most of the 772,000 new jobs created in Spain in 2006 went to immigrants (about 60\%). Their motivation to work hard also opened the way for productivity improvements (which in 2006 experienced the largest increase since 1997 , with a $0.8 \%$ raise). It is estimated that the contribution of immigrants to GDP had been of 0.8 percentage points in the four years to 2007.9 Immigration represented more than $50 \%$ of employment growth, and $78.6 \%$ of the demographic growth (as a result Spain led the demographic growth of the European countries between 1995 and 2005 with a demographic advance of $10.7 \%$ compared with the EU15 average of $4.8 \%) .{ }^{10}$ They also contributed to the huge increase in employment, which was one of the key reasons for the impressive economic expansion. Indeed, between 1988 and 2006, employment contributed 3 percentage points to the $3.5 \%$ annual rise in Spain's potential GDP (see Table 4.1). ${ }^{11}$

\section{The Basis for Success}

What made this transformation possible? The modernization of the Spanish economy in the two and half decades prior to 2008 had been intimately connected to the country's integration in the European Union. Indeed, European integration was a catalyst for the final conversion of the Spanish economy into a modern Western-type economy. Yet, membership was not the only reason for this development. The economic liberalization, trade integration, and modernization of the Spanish economy started in the 1950s and 1960s and Spain became increasingly prosperous over the two decades prior to EU accession. However, one of the

\footnotetext{
${ }^{9}$ Guillermo de la Dehesa, "La Próxima Recesión," El Pais, January 21, 2007.

10 "La Economía española creció en la última década gracias a la aportación de los inmigrantes," El Pais, Monday, August 28, 2006.

${ }^{11}$ See Martin Wolf, "Pain Will Follow Years of Economic Gain," Financial Times, March 29, 2007.
} 
key consequences of its entry into Europe was that it consolidated and deepened that development processes, and it accelerated the modernization of the country's economy. Indeed, EU membership facilitated the micro- and macroeconomic reforms that successive Spanish governments undertook throughout the 1980s and 1990s. Spain also benefited extensively from European funds those two decades: approximately 150 billion euros from agricultural, regional development, training, and cohesion programs.

Moreover, European Monetary Union (EMU) membership was also very positive for the country: it contributed to macroeconomic stability, it imposed fiscal discipline and central bank independence, and it lowered dramatically the cost of capital. One of the key benefits was the dramatic reduction in short-term and long-term nominal interest rates: from $13.3 \%$ and $11.7 \%$ in 1992 , to $3.0 \%$ and $4.7 \%$ in 1999 , and $2.2 \%$ and $3.4 \%$ in 2005. The lower costs of capital led to an important surge in investment from families (in housing and consumer goods) and businesses (in employment and capital goods). Indeed, EMU membership (and the Stability Pact) provided the country with unprecedented stability because it forced successive governments to implement responsible economic policies, which led to greater credibility and the improvement of the ratings of Spain's public debt (and consequently to lower financing costs).

Another important factor to account for the country's economic success was the remarkable economic policy stability that followed the economic crisis of 1992-1993. Indeed, there were few economic policy shifts throughout the 1990s and early 2000s, and this despite changes in government. Between 1993 and 2009, there were only two Ministers of Finance, Pedro Solbes (from 1993 to 1996, and from 2004 to 2009) and Rodrigo Rato (from 1996 to 2004); and the country only had three Prime Ministers (Felipe González, José María Aznar, and José Luís Rodríguez Zapatero). This pattern was further reinforced by the ideological cohesiveness of the political parties in government and the strong control that party leaders exercise over the members of the cabinet and the parliament deputies.

In addition, this stability was reinforced by the shared (and rare) agreement among Conservative and Socialist leaders regarding fiscal consolidation (the balance budget objective was established by law by the Popular Party), as well as the need to hold firm in the application of restrictive fiscal policies and the achievement of budgetary surpluses: As a 
result, a $7 \%$ budget deficit in 1993 became a $2.2 \%$ surplus in 2007 , and public debt decreased from 68\% of GDP in 1998 to $36.2 \%$ in 2007.

Finally, other factors that contributed to this success included the limited corruption and the fact that politics were fairly clean and relatively open; that Spain had a flexible economy; and the success of Spanish multinationals: There were eight firms in the Financial Times list of the world's largest Multinationals in 2000, and 14 in $2008 .^{12}$

\section{The Challenges}

However, this economic success was marred by some glaring deficiencies that came to the fore in 2008 when the global financial crisis hit the country, because it was largely a "miracle" based on bricks and mortar. ${ }^{13}$ The foundations of economic growth were fragile because the country had low productivity growth (productivity contributed only 0.5 percentage points to potential GDP between 1998 and 2006) and deteriorating external competitiveness. ${ }^{14}$ Over the decade that preceded the 2008 crisis Spain did not address its fundamental challenge, its declining productivity, which only grew an average of $0.3 \%$ during that decade $(0.7 \%$ in 2006$)$, one whole point below the EU average, placing Spain at the bottom of the EU and ahead of only Italy and Greece (the productivity of a Spanish worker was the equivalent of $75 \%$ of a US one). The most productive activities (energy, industry, and financial services) contributed only $11 \%$ of GDP growth. ${ }^{15}$

${ }^{12}$ According to 2007 data from the World Bank Governance Indicators (http://info. worldbank.org/governance/wgi/sc_chart.asp), Spain was ranked in the 75-100th country's percentile ranks in control of corruption, government effectiveness, regulatory quality, rule of law, and voice and accountability.

${ }^{13}$ According to Martinez-Mongay and Maza Lasierra, "The outstanding economic performance of Spain in EMU would be the result of a series of lucky shocks, including a large and persistent credit impulse and strong immigration, underpinned by some right policy choices. In the absence of new positive shocks, the resilience of the Spanish economy to the financial crisis might be weaker than that exhibited in the early 2000s. The credit impulse has ended, fiscal consolidation has stopped, and the competitiveness gains of the nineties have gone long ago." See Martinez-Mongay and Maza Lasierra (2009).

14 "Fears of Recession as Spain Basks in Economic Bonanza," Financial Times, Thursday, June 8, 2006.

15 "Los expertos piden cambios en la política de I+D," El País, Monday, December 18, 2006. 
Moreover, growth was largely based on low-intensity economic sectors, such as services and construction, which were not exposed to international competition. In 2006, most of the new jobs were created in low-productivity sectors such as construction (33\%), services associated with housing such as sales and rentals (15\%), and tourism and domestic service $(30 \%)$. These sectors represented $75 \%$ of all the new jobs created in Spain in 2006 (new manufacturing jobs, in contrast, represented only $5 \%$ ). Furthermore, the labor temporary rate reached $33.3 \%$ in 2007 , and inflation was a recurrent problem (it closed 2006 with a $2.7 \%$ increase, but the average for that year was 3.6\%), thus the inflation differential with the EU (almost 1 point) had not decreased, which reduced the competitiveness of Spanish products abroad (and consequently Spanish companies were losing market share abroad). ${ }^{16}$ Competitiveness was further hindered by a deep process of economic deindustrialization, low value added and complexity of exports, and low insertion in global value chains.

In addition, family indebtedness reached a record $115 \%$ of disposable income in 2006, and the construction and housing sectors accounted for $18.5 \%$ of GDP (twice the Eurozone average). House prices rose by $150 \%$ since 1998, and the average price of a square meter of residential property went up from 700 Euros in 1997 to 2000 at the end of 2006, even though the housing stock had doubled. Many wondered whether this bubble was sustainable. ${ }^{17}$ The crisis that started in 2008 confirmed the worst fears, and the implosion of the housing bubble fueled corruption and bad practices in the cajas sector of the financial system.

Moreover, between 40 and $60 \%$ of the benefits of the largest Spanish companies came from abroad. Yet, in the years prior to the crisis this figure had decreased by approximately 10 percentage points, and there had been a decline in direct foreign investment of all types in the country, falling from a peak of 38.3 billion euros in 2000 to 16.6 billion euros in $2005 .{ }^{18}$ The current account deficit reached $8.9 \%$ of GDP in 2006 and over $10 \%$ in 2007 , which made Spain the country with the largest deficit in absolute terms (86,026 million euros), behind only the United

${ }^{16}$ Angel Laborda, "El comercio en 2006," El Pais, Sunday, March 11, 2007, p. 20.

${ }^{17}$ Wolfgang Munchau, "Spain, Ireland and Threats to the Property Boom," Financial Times, Monday, March 19, 2007; "Spain Shudders as Ill Winds Batter US Mortgages," Financial Times, Wednesday, March 21, 2007.

18 "Spanish Muscle Abroad Contrast with Weakling Status among Investors," Financial Times, December 11, 2006. 
States; imports were $25 \%$ higher than exports and Spanish companies were losing market share in the world. Hence, the trade deficit reached 9.5\% in $2008 .^{19}$

While there was overall consensus that the country needed to improve its education system and invest in research and development to lift productivity, as well as modernize the public sector, and make the labor market more stable (i.e., reduce the temporary rate) and flexible, the government did not take the necessary actions to address these problems. Spain spent only half of what the Organization of European Co-operation and Development (OECD) countries spent on average on education; it lagged most of Europe on investment in Research and Development $(\mathrm{R} \& \mathrm{D})$; and it was ranked 29th by the UNCTAD as an attractive location for research and development. Finally, other observers noted that Spain was failing to do more to integrate its immigrant population, and social divisions were beginning to emerge. ${ }^{20}$

By the summer of 2008, the effects of the global crisis were evident in Spain, and between 2008 and 2013 the country suffered one of the worst recession in modern history. This collapse was not wholly unexpected. The global liquidity freeze and the surge in commodities, food, and energy prices brought to the fore the unbalances in the Spanish economy: the record current account deficit, persisting inflation, low productivity growth, dwindling competitiveness, increasing unitary labor costs, excess consumption, and low savings, had all set the ground for the current devastating economic crisis (see Royo 2013).

\section{After the Fiesta: The Global Crisis Hits Spain}

As we have seen, the imbalances in the Spanish economy came to the fore in 2007-2008 when the real estate market bubble burst and the international financial crisis hit Spain (see Table 4.2). In just a few months the 'debt-fired dream of endless consumption' turned into a nightmare. By the summer of 2013, Spain faced the worst economic recession in half a century. According to government statistics, 2009 was the worst year since there has been reliable data: GDP fell 3.7\%, unemployment

19 "La Comisión Europea advierte a España de los riesgos de su baja competitividad," El Pais, February 4, 2007.

20 "Zapatero Accentuates Positives in Economy, but Spain Has Other Problems," Financial Times, April 16, 2007, p. 4. 
Table 4.2 The economic crisis: 2008-2013

\begin{tabular}{llrrrrrrr}
\hline Subject descriptor & Units & 2007 & 2008 & 2009 & 2010 & 2011 & 2012 & 2013 \\
\hline $\begin{array}{l}\text { Gross domestic } \\
\text { product, constant } \\
\text { prices }\end{array}$ & \% change & 3.5 & 0.9 & -3.8 & -0.3 & 0.4 & -1.4 & -1.6 \\
$\begin{array}{l}\text { Output gap in percent } \\
\text { of potential GDP }\end{array}$ & \% & & & & & & & \\
& $\begin{array}{l}\text { potential } \\
\text { GDP }\end{array}$ & 3.8 & 2.3 & -2.8 & -3.4 & -3.2 & -4.5 & -5.4 \\
$\begin{array}{l}\text { Total investment } \\
\text { \% GDP }\end{array}$ & 31.0 & 29.1 & 24.0 & 22.8 & 21.5 & 19.6 & 18.1 \\
$\begin{array}{l}\text { Inflation, average } \\
\text { consumer prices }\end{array}$ & \% change & 2.8 & 4.1 & -0.2 & 2.0 & 3.1 & 2.4 & 1.9 \\
Unemployment rate & \% total & 8.3 & 11.3 & 18 & 20.1 & 21.7 & 25 & 27 \\
$\begin{array}{l}\text { labor } \\
\text { force }\end{array}$ & & & & & & & \\
\% & -1.1 & -5.4 & -9.5 & -8.0 & -7.8 & -5.7 & -4.5 \\
$\begin{array}{l}\text { General government } \\
\text { structural balance }\end{array}$ & $\begin{array}{l}\text { potential } \\
\text { GDP }\end{array}$ & & & & & & & \\
$\begin{array}{l}\text { General government } \\
\text { net debt }\end{array}$ & \%DP & 26.7 & 30.8 & 42.5 & 49.8 & 57.5 & 71.9 & 79.1 \\
$\begin{array}{l}\text { Current account } \\
\text { balance }\end{array}$ & \% GDP & -1.0 & -9.6 & -4.8 & -4.5 & -3.7 & -1.1 & 1.1 \\
\hline
\end{tabular}

Source International Monetary Fund, World Economic Outlook Database, April 2014

reached over four million people (eventually reaching over $27 \%$ in 2012 , with more than 6 million people unemployed), and the public deficit reached a record $11.4 \%$ of GDP (up from $3.4 \%$ in 2008). Consumer confidence was shattered, the implosion of the housing sector reached historic proportions, and the manufacturing sector was also suffering.

Initially, the Zapatero government was reluctant to recognize the crisis, which was becoming evident as early as the summer of 2007, because of electoral considerations: The country had a general election in March 2008. And after the election, the Zapatero government was afraid to admit that it had not been entirely truthful during the campaign. By 2007, there was increasing evidence that the model based on construction was already showing symptoms of exhaustion. Yet, the Spanish government not only refused to recognize that the international crisis was affecting the country, but also that in Spain the crises would be aggravated by the very high levels of private indebtedness. As late as August 17, 2007, Finance Minister Solbes predicted that 'the crisis would have a relative small effect' in the Spanish economy. 
When it became impossible to deny what was evident, the government's initial reluctance to recognize and address the crisis was replaced by frenetic activism. The Zapatero government introduced a succession of plans and measures to try to confront the economic crisis, and specifically to address the surge of unemployment (Royo 2013) (see Fig. 4.1).

The sharp deterioration of the labor market was caused by the economic crisis and the collapse of the real estate sector, and it was aggravated by a demographic growth pattern based on migratory inflows of labor: In 2007, there were 3.1 million immigrants in the country, of which 2.7 million were employed and 374,000 unemployed. In 2008, the number of immigrants increased by almost $400,000-3.5$ million (representing $55 \%$ of the growth in the active population), but 580,000 of them were unemployed (and 2.9 million employed), an increase of 200,000 . In the construction sector alone, unemployment increased $170 \%$ between the summer of 2007 and 2008. Meanwhile, the manufacturing and service sectors (also battered by the global crisis, lower consumption, and lack of international competitiveness) proved unable to incorporate these workers.

The pace of deterioration caught policy-makers by surprise. The Zapatero government prepared budgets for 2008 and 2009 that were utterly unrealistic in the face of rapidly changing economic circumstances

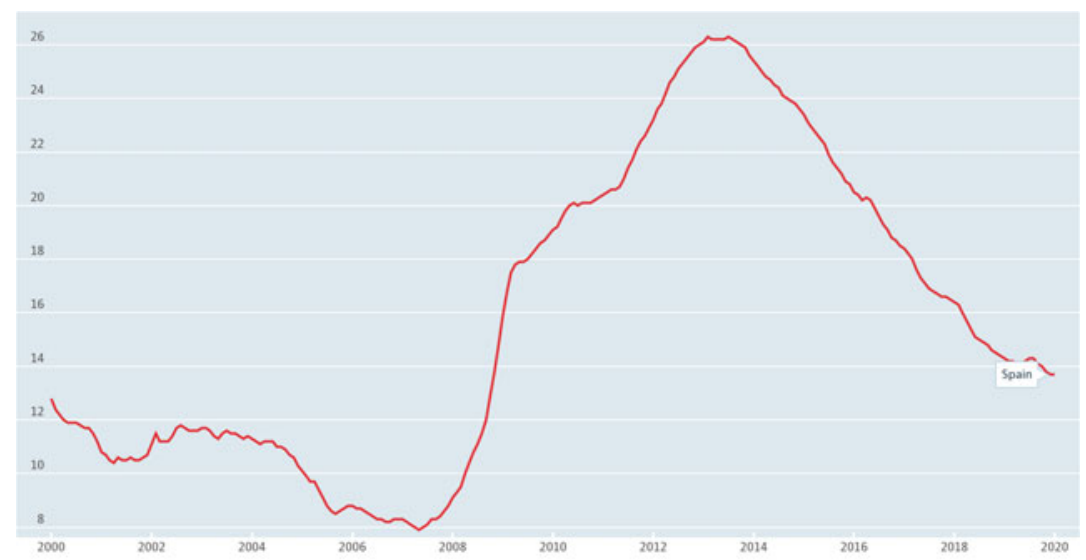

Fig. 4.1 Unemployment rate (2000-2020) (Source OECD Labor market statistics) 
(as did all other advanced countries, the G-20 agreed on a plan for fiscal stimulus that would later prove relatively ineffective and dangerous for Spain as it increased the country's debt). As a result, things continued to worsen over the new four years. The most significant decline was in consumer confidence, which was hammered by the financial convulsions, the dramatic increase in unemployment, and the scarcity of credit. As a result, household consumption, which represented $56 \%$ of GDP, fell $1 \%$ in the last quarter of 2009 for the first time in the last 15 years. According to the Bank of Spain, this decline in household consumption was even more important in contributing to the recession than the deceleration of residential investment, which had fallen $20 \%$, driven down by worsening financial conditions, uncertainties, and the drop in residential prices. The government actions had limited effect stemming this hemorrhage, and their efficacy was inadequate.

Finally, the impact of the global economic crisis was felt well beyond the economic and financial realms. The crisis also had severe political consequences. Spain followed in the path of many other European countries (including Ireland, Portugal, Greece, and France) that saw their governments suffer the wrath of their voters and have been voted out of office. The Socialist Party (PSOE) was re-elected in a general election on March 9, 2008. Soon thereafter, economic conditions deteriorated sharply and the government's popularity declined rapidly. Between March 2008 and March 2012, there were a number of electoral contests in Spain at the local, regional, national, and European levels. At the national and European levels, the one common pattern was the outcome: the defeat of the Socialist Party and the victory of the Popular Party (PP). And at the regional and local levels the Socialists suffered historical losses, losing control of regional government that they ruled for decades (notably, Castilla-La Mancha and Extremadura), and even losing the election for the first time in one of its historical strongholds, Andalusia (although they were able to reach a coalition with a smaller leftist party to stay in power). In the end, the economic crisis ignited a pattern of political polarization, instability, and fragmentation of the party system that crystallized in 2015 (following the PP's absolute majority) and lasts through today: As of fall of 2019, Spain has had 4 general elections in 4 years. 


\section{The Triple Crisis}

\section{The Fiscal Crisis}

One of the most common misinterpretations regarding the crisis in Southern Europe was attributing it to mismanaged public finances. Many policy-makers across Europe, especially in the creditor countries (crucially Germany), still insist today (2019) that the crisis was caused by irresponsible public borrowing, and this, in turn, led to misguided solutions. In fact, with very few exceptions, notably Greece, that interpretation is incorrect. In Spain, the crisis did not originate with mismanaged public finances. On the contrary, as late as 2011, Spain's debt ratio was still well below the average for countries that adopted the euro as a common currency: While Spain stood at less than $60 \%$ of GDP, Greece stood at $160.8 \%$, Italy at $120 \%$, Portugal at $106.8 \%$, Ireland at $105 \%$, Belgium at $98.5 \%$, and France at $86 \%$. On the contrary, prior to 2007 , Spain seemed to be in an enviable fiscal position, even when compared with Germany. ${ }^{21}$ Spain ran a budget surplus in 2005,2006 , and 2007. It was only when the crisis hit the country and the real estate market collapsed that the fiscal position deteriorated markedly and the country experienced huge deficits.

The problem in Spain was the giant inflow of capital from the rest of Europe; the consequence was rapid growth and significant inflation. In fact, the fiscal deficit was a result, not a cause, of Spain's problems: When the global financial crisis hit Spain and the real estate bubble burst, unemployment soared, and the budget went into deep deficit, caused partly by depressed revenues and partly by emergency spending to limit human costs. The government responded to the crisis with a massive $€ 8$ billion public works stimulus. This decision, combined with a dramatic fall in revenue, blew a hole in government accounts resulting in a large deficit.

Furthermore, the conditions for the crisis in Spain were created by the excessive lending and borrowing of the private sector rather than the government. In other words, the problem was private debt and not public debt. Spain experienced a problem of ever-growing private sector indebtedness, which was compounded by the reckless investments and loans of banks (including the overleveraged ones), both integral components of

${ }^{21}$ See Martin Wolf's blog: "What Was Spain Supposed to Have Done?" June 25, 2012, http://blogs.ft.com/martin-wolf-exchange/2012/06/25/what-was-spain-sup posed-to-have-done. 
the bank bargains that we examine later in the book, that were aggravated by competitiveness and current account imbalances. In Spain, the private sector debt (households and nonfinancial corporations) was $227.3 \%$ of GDP at the end of 2010 ; total debt increased from $337 \%$ of GDP in 2008 to $363 \%$ in mid- 2011 .

Yet, although Spain entered the crisis in a relatively sound fiscal position, that position was not solid enough to withstand the effects of the crisis, especially being a member of a dysfunctional monetary union with no lender of last resort. The country's fiscal position deteriorated sharply - collapsing by more than 13\% of GDP in just two years. Looking at the deficit figures with the benefit of hindsight, it could be argued that Spain's structural or cyclically adjusted deficit was much higher than its actual deficit. The fast pace of economic growth before the crisis inflated government revenues and lowered social expenditures in a way that masked the vulnerability hidden in Spanish fiscal accounts. The problem is that it is very difficult to know the structural position of a country. The only way in which Spain could have prevented the deficit disaster that followed would have been to run massive fiscal surpluses of $10 \%$ or higher during the years prior to the crisis in order to generate a positive net asset position of at least $20 \%$ of GDP. ${ }^{22}$ This, for obvious reasons, would not have been politically feasible.

\section{The Loss of Competitiveness}

There is another way to look at the crisis. Many economists argue that the underlying problem in the euro area was the exchange rate system itself, namely, the fact that European countries locked themselves into an initial exchange rate. This decision meant, in fact, that they believed that their economies would converge in productivity (which would mean that the Spaniards would, in effect, become more like the Germans). If convergence was not possible, the alternative would be for people to move to higher productivity countries, thereby increasing their productivity levels by working in factories and companies there (or to create a full fiscal union to provide for permanent transfers, as argued by OCA theory). Time has shown that both expectations were unrealistic and, in fact, the opposite happened. The gap between German and Spanish (including other

${ }^{22}$ From Martin Wolf's blog: "What Was Spain Supposed to Have Done?" June 25, 2012 . 
peripheral country) productivity increased, rather than decreased, over the past decade and, as a result, Germany developed a large surplus on its current account; while Spain and the other periphery countries had large current account deficits that were financed by capital inflows. ${ }^{23}$ In this regard, one could argue that the incentives introduced by EMU worked exactly in the wrong way. Capital inflows in the south made the structural reforms that would have been required to promote convergence less necessary, thus increasing divergence in productivity levels.

In addition, adoption of the euro as a common currency fostered a false sense of security among private investors. During the years of euphoria following the launching of Europe's economic and monetary union and prior to the onset of the financial crisis, private capital flowed freely into Spain and, as a result as we have seen, the country ran current account deficits of close to $10 \%$ of GDP. In turn, these deficits helped finance large excesses of spending over income in the private sector. The result did not have to be negative. These capital inflows could have helped Spain (and the other peripheral countries) invest, become more productive, and "catch up" with Germany. Unfortunately, in the case of Spain, they largely led to a massive bubble in the real estate market, consumption, and unsustainable levels of borrowing. The bursting of that bubble contracted the country's real economy and it brought down the banks that gambled on loans to real estate developers and construction companies.

At the same time, as noted above, the economic boom also generated large losses in external competitiveness that Spain failed to address. Successive Spanish governments also missed the opportunity to reform institutions in their labor and product markets. As a result, costs and prices increased, which in turn led to a loss of competitiveness and large trade deficits. This unsustainable situation came to the fore when the financial shocks that followed the collapse of Lehman Brothers in the fall of 2007 brought "sudden stops" in lending across the world, leading to a collapse in private borrowing and spending, and a wave of fiscal crisis.

\section{The Financial Crises}

A third problem had to do with the banks. As we will see in much greater detail later in the book, this problem was slow to develop. Between

${ }^{23}$ Simon Johnson's blog: “The End of the Euro: What's Austerity Got to Do With It?” June 21, 2012. 
2008 and 2010, the Spanish financial system, despite all its problems, was still one of the least affected by the crisis in Europe. During that period, of the 40 financial institutions that received direct assistance from Brussels, none was from Spain. In December 2010, Moody's ranked the Spanish banking system as the third strongest of the Eurozone, only behind Finland and France, above the Netherlands and Germany, and well ahead of Portugal, Ireland, and Greece. Finally, Santander and BBVA had shown new strength with profits of $€ 4.4$ billion and $€ 2.8$ billion, respectively, during the first half of 2010. Spanish regulators had put in place regulatory and supervisory frameworks, which initially shielded the Spanish financial system from the direct effects of the global financial crisis. Indeed, the Bank of Spain had imposed a regulatory framework that required higher provisioning, which provided cushions to Spanish banks to initially absorb the losses caused by the onset of the global financial crisis. And there were no toxic assets in bank's balance sheets.

Nevertheless, this success proved short-lived. In the summer of 2012, Spanish financial institutions seemed to be on the brink of collapse and the crisis of the sector forced the European Union in June (2012) to devise an emergency $€ 100$ billion rescue plan for the Spanish banking sector (see Chapter 1). When the crisis intensified, the financial system was not able to escape its dramatic effects. By September 2012, the problem with toxic real estate assets forced the government to intervene and nationalize eight financial institutions. Altogether, by May 9, 2012, the reorganization of the banking sector involved $€ 115$ billion in public resources, including guarantees.

As we will examine later in the book, there are a number of factors that help account for the deteriorating performance of the Spanish banks after 2009. The first was the direct effect of the economic crisis. The deterioration in economic conditions had a severe impact on the bank balance sheets. The deep recession and record-high unemployment triggered successive waves of loan losses in the Spanish mortgage market coupled with a rising share of nonperforming loans. Like many other countries such as the United States, Spain had a huge property bubble that burst. Land prices increased 500\% in Spain between 1997 and 2007, the largest increase among the OECD countries. As a result of the collapse of the real estate sector had a profound effect in banks: Five years after the crisis started, the quality of Spanish banking assets continued to plummet. The Bank of Spain classified $€ 180$ billion euros as troubled assets at the 
end of 2011, and banks were sitting on $€ 656$ billion of mortgages of which $2.8 \%$ were classified as nonperforming.

A second factor was concern over the country's sovereign debt. As mentioned before, the crisis in Spain did not originate with mismanaged public finances. The crisis has largely been a problem of ever-growing private sector debt, compounded by reckless bank investments and loans, particularly from the cajas, as well as aggravated by competitiveness and current account imbalances. To place the problem in perspective, the gross debt of household increased dramatically in the decade prior to the crisis, and by 2009 it was 20 percentage points higher than the Eurozone average ( $86 \%$ of GDP versus $66 \%$ ). But the austerity policies implemented since May 2010 aggravated the fiscal position of the country. The ratio of Spain's debt to its economy was 36\% before the crisis and reached $84 \%$ in 2013. In sum, Spain fell into the "doom loop" that had already afflicted Greece or Portugal and led to their bailout. The sustainability of the Spanish government debt was affecting Spanish banks (including BBVA and Santander) because they had been some of the biggest buyers of government debt in the wake of the ECB long-term refinancing operation liquidity infusions (the percentage of government bond owned by domestic banks reached 30\% in mid-2012). Again, the doom loop was a result of EMU weakness, namely the lack of a banking union with a centralized EU funded mechanism to bail out banks.

Spanish banks were also suffering the consequences of their dependence on wholesale funding for liquidity since the crisis started, and, in particular, their dependence on international wholesale financing, as $40 \%$ of their balance depends on funding from international markets, particularly from the ECB. Borrowing from the ECB reached $€ 82$ billion in 2012, and Spanish banks had increased their ECB borrowings by more than six times since June 2011, to the highest level in absolute terms among Euro area banking systems as of April 2012.

The crisis also exposed weaknesses in the policy and regulatory framework, part of the banking bargains that we will examine later in the book. The most evident sign of failure was the fact that the country had already adopted five financial reforms in three years and had implemented three rounds of bank mergers. The results of these reforms were questionable at best. The fact that Spain had five reforms in less than three years, instead of one that really fixed the problem, says it all. They had been perceived largely as "too little and too late," and they failed to sway investors' confidence in the Spanish financial sector. 
Finally, the financial crisis can also be blamed on the actions (and inactions) of the Bank of Spain, one of the key actors involved in the bank bargains. At the beginning of the crisis, the Bank of Spain's policies were all praised and were taken as model by other countries. Time, however, tempered that praise and the Bank of Spain was criticized for its actions and decisions (or lack thereof) during the crisis. Spanish central bankers chose the path of least resistance: alerting about the risks but failing to act decisively.

\section{CONCLUSION}

The economic crisis that started in Spain 2008 was largely a problem of ever-growing private sector debt, aggravated by competitiveness and current account imbalances, and compounded by reckless bank investments and loans, particularly from the cajas, which by over-lending freely to property developers and mortgages contributed to a real estate property bubble. This outcome was a result of the political bargains at the heart of the game of bank bargains focus of this book. The bubble contributed to hide the fundamental structural problems of the Spanish economy outlined in the previous sections and had an effect in policy choices because no government was willing to burst the bubble and risk suffering the wreath of voters. Furthermore, cheap credit also had inflationary effects that contributed to competitiveness losses and record balance of payment deficits. Therefore, three dimensions of the crisis (financial, fiscal, and competitiveness) are interlinked in their origins. The crisis exposed the underbelly of the financial sector and showed that many banks (particularly the cajas) were not just suffering liquidity problems but risked insolvency, which led to the EU financial bailout of June 2012. The bailout had onerous conditions attached and it limited national economic autonomy (see Dellepiane and Hardiman 2011). Finally, the financial and fiscal crises were made worse by the incomplete institutional structure of EMU and by bad policy choices at the EU level (excess austerity and refusal to act as a lender of last resort for sovereigns by the ECB) (Royo 2013).

In the end, the crisis exposed the weaknesses of the country's economic model. Indeed, despite the previous two decades' significant progress and achievements, the Spanish economy still faced serious competitive and fiscal challenges. Unfortunately, the economic success the country prior to the crisis fostered a sense of complacency, which allowed for a delay 
in the adoption of the necessary structural reforms. And this was not a surprise as the Spanish economy was living on borrowed time, despite all the significant progress, and the country still had considerable ground to cover, given the existing income and productivity differentials, to catch up with the richer EU countries and to improve the competitiveness of its economy (see Royo 2013).

The sudden collapse of the Spanish economy came as a shock. Yet, in retrospect it should not have been such a surprise. The policies choices and political bargains taken during the previous decades led to an unsustainable bubble in private sector borrowing that was bound to burst. Moreover, as we will examine on Chapter 7, the institutional degeneration that led to systemic corruption and contributed to the implosion of parts of the financial sector made the crisis almost unavoidable.

As we have seen, much of Spain growth during the 2000s was based on the domestic sector and particularly on an unsustainable reliance on construction. As we will later in the book, this outcome was part of a political bargain in which tax incentives and a lax regulatory framework favored developers, property owners, and bankers (particularly cajas). The particular regulation of the cajas proved fatally flawed, as it provided incentives that favored local and regional government actors' access to finance at the expense of an environment that would have provided a stable and efficient banking system. On the contrary, it led to a form of crony capitalism Spanish style, in which they invested massively in the construction sector in search of rapid growth and larger market share. These decisions proved fatal once the real estate bubble burst, and they led to the nationalization of several cajas, including Bankia, and the financial bailout from the European Union.

Membership in the European single currency was not the panacea that everyone expected to be, thus confirming the crucial importance of domestic political institutions and how domestic players operate within those institutions. In Spain, the adoption of the euro led to a sharp reduction in real interest rates that contributed to the credit boom and the real estate bubble. However, it also altered economic governance decisions. Successive Spanish governments largely ignored the implications of EMU membership and failed to implement the necessary structural reforms to ensure the sustainability of fiscal policies and to control unitary labor costs. These decisions led to a continuing erosion of competitiveness (and a record current account deficit), and a huge fiscal deficit when the country was hit by the global financial crisis. 
Indeed, the experience of the country shows that EU and EMU membership had not led to the implementation of the structural reforms necessary to address these challenges. On the contrary, EMU contributed to the economic boom, thus facilitating the postponement of necessary economic reforms. This challenge however is not a problem of European institutions, but of national policies. The process of economic reforms has to be a domestic process led by domestic actors willing to carry them out.

The Spanish case serves as an important reminder that in the context of a monetary union, countries only control fiscal policies and relative labor costs. Spain proved to be weak at both. It failed to develop an appropriate adjustment strategy to succeed within the single currency, and it ignored the imperative that domestic policy choices have to be consistent with the international constraints imposed by euro membership. On the contrary, in Spain domestic policies and the imperatives of participating in a multinational currency union stood in uneasy relationship to one another. The crisis was the tipping point that brought this inconsistency to the fore, which led to the worst economic crisis in Spanish modern history (before COVID-19). Next we turn to the elements of domestic bargains that underline the financial crisis.

\section{REFERENCES}

Calavita, Kitty. Immigrants at the Margins. New York: Cambridge University Press, 2005.

Dellepiane, Sebastián, and Niamh Hardiman. "Governing the Irish Economy." UCD Geary Institute Discussion Series Chapters, Geary WP2011/03, University College Dublin, Dublin, February 2011.

Guillén, Mauro. The Rise of Spanish Multinationals. Cambridge: Cambridge University Press, 2005.

Martinez-Mongay, Carlos, and Luís Angel Maza Lasierra. "Competitiveness and Growth in EMU: The Role of the External Sector in the Adjustment of the Spanish Economy." Economic Papers, No. 355, October 2009.

Royo, Sebastián. From Social Democracy to Neoliberalism. New York: St. Martin's Press, 2000.

Royo, Sebastián. Varieties of Capitalism in Spain. New York: Palgrave, 2008.

Royo, Sebastián. Lessons from the Economic Crises in Spain. New York: Palgrave, 2013.

Royo, Sebastián. "After Austerity: Lessons from the Spanish Experience." In Towards a Resilient Eurozone: Economic, Monetary and Fiscal Policies, edited by John Ryan. New York: Peter Lang, 2015. 